\title{
Structural vs. cognitive poetics: Approaches to the study of poetic syntax
}

\author{
I. E. Grachova, A. V. Mosiichuk \\ Vinnytsia Mykhailo Kotsyubyns'kyi State Pedagogical University, Vinnytsia, Ukraine \\ Corresponding author. E-mail: ira.gracheva77@gmail.com
}

Paper received 25.05.18; Accepted for publication 01.06.18.

https://doi.org/10.31174/SEND-Ph2018-167VI50-05

\begin{abstract}
The paper examines the study of poetic syntax from the standpoint of structural and cognitive poetics. The results of the research show that depending on the perspective taken, the analyzed fields single out their own units, methods, and principles of research, which facilitate the investigation of poetic syntax. The paper claims that at present the most complete study of the syntactic organization of poetry texts is provided within cognitive poetics, an innovative branch of philology dealing with the linguistic and cognitive mechanisms of formation and functioning of literary texts and their elements.
\end{abstract}

Key words: poetic syntax, poetics, poetry text, syntactic unit, construction.

Introduction. Linguistic and literature studies have witnessed different approaches to the interpretation of poetic syntax, each of them being determined by the focus and scope of particular research paradigms. The study of the syntactic organization of poetry texts is most effective when conducted in terms of poetics, a branch of philology focusing on the form, methods, and principles of analysis of poetry and, in a broader sense, literary texts [9, p. 54]. The present study is going trace the specifics of poetic syntax research within structural and cognitive poetics.

Literature Overview. The ideas of F. de Saussure's [24] classical structural linguistics influenced the formation of three basic directions in the analysis of poetic speech: the Prague Linguistic Circle $[18 ; 19 ; 30]$, French literary structuralism [4; 27], and the Tartu-Moscow Semiotic School [16, 17, 29]. Despite the geographical distance of these trends, the vector of scientific interest was directed towards a common object of research - the language of literary works. However, each division of structural poetics focused on a certain aspect thereby determining the specificity of studying the text and its levels. Although structural poetics formed an efficient launching pad for the analysis of poetry texts, an acute interest in studying language with regard to humans who take an active part in the processes of cognition and speech production [5, p. 24] necessitated moving further to examining language as a cognitive mechanism encompassing data organization, processing, and transmission [ibid.: 22]. The viability of the conceptual base of cognitive linguistics in investigating literary texts led to the emergence of an innovative linguistic branch known as cognitive poetics. An essential prerequisite for studying literary texts from the standpoint of cognitive poetics is using certain strategies and techniques of analysis, which reveal the mechanisms of embodying the author's preconceptual and conceptual experience in the texture [28, p. 4].

The objective of the paper is to trace the rationale for studying poetic syntax within structural and cognitive poetics accentuating the similarities and differences of the above-mentioned approaches in a bid to reveal the more effective of the two.

The research material and methods. The research material is represented by texts of modernist and postmodernist American poetry. The methodology of the research encompasses general scientific methods, such as induction, deduction, analysis, and synthesis, as well as specialized methods of linguistic analysis, in particular, the methods of conceptual, interpretative, and contextual analysis.

Results and Discussion. Following F. de Saussure, the representatives of the structural-functional approach recognized the systemic and structural features of the language, emphasizing the importance of analyzing literary and poetic languages as specific sign systems [18, p. $270 ; 26$, p. 21]. Proceeding from the above, poetic text was viewed as a functional structure, with the units of all levels examined in terms of their functional purpose and interconnection. Consequently, the aesthetic or poetic function was recognized as the dominant principle of a poem's organization. The latter was revealed in the selfrelevance of text elements aiming not at the designation of the referents of the surrounding world, but at the sign system as such $[27$, p. 25, 31]. The poetic function resulted in "poetization" of a literary text manifested in the condensation of the meaning of a poetic message, which produces an aesthetic effect on the addressee. The Prague scientists investigated words, phrases, and sentences as the main poetic syntactic units viewing them not only as a means of verse ordering but also as bearers of meaning, which fully reveal their semantic potential in the context of a literary work [ibid.: 282-283, 334]. In line with the principles outlined above, syntactic poetic units were studied in terms of their specific nature and were differentiated from those of ordinary language. Whereas the purpose of the latter was to denote objects of language reality, which made them unobtrusive and automated for the addressee, the function of poetic syntax was associated with its autonomous value that provided actualization the usage of linguistic means, which "attract attention and are perceived as something unusual, devoid of automatism, or deautomated" [2, p. 66]. Due to their connection with the rhythmic and semantic structures of the poetry text, syntactic units were considered to have unlimited possibilities for actualization, provided by different variants of their formal organization and the appearance of specific syntactic forms (e.g., complex sentences with various types of subordination), not inherent in ordinary language [ibid.: 27].

The structural-semiotic direction of the poetic syntax research emerged from the activity of two schools: the French literary structuralism and the Tartu-Moscow semiotic school. The semiological conception of L. Hjelmslev, the concepts of denotative and connotative semiotics [7] in particular, formed the theoretical and methodological foundation for the works of the French structuralists and R. Bart [4] specifically. From the standpoint of the struc- 
tural-semiotic approach, syntactic studies aim at the description of sentences $[10$, p. $28 ; 27$, p. 202] realized with respect to linguistic registers of figurativity and transparency. In this context, figurativity refers to a characteristic of sentences containing rhetorical figures: syntactic unities with certain word order, which can be named or described. The relations between the parts of the figure identity, contrast, and increase or decrease in number serve as the criteria of singling out figures of repetition, antithesis, and gradation respectively. The register of transparency constitutes the antinomy of figurativity and is ascribed to sentences with the so-called "unnoticeable" verbal cover whose main purpose is not creating a poetic effect but conveying information [4, p. 56-57].

In turn, the representatives of the Tartu-Moscow semiotic school Yu. Lotman [16, 17] and B. Uspenskiy [29] proceed from the systemic character of poetic texts and levels of their organization. In this context, the system of a poetic text is defined as a set of units, or signs, ordered in a certain way for the purpose of fixating, storing, and transferring information [17, p. 282]. The main parameters of a literary text characterizing it as a system are: 1) expression, or fixation, in signs; 2) detachment of the text or its contrast to other signs, which do not belong to it; 3 ) structurality, i.e. the presence of certain inner organization, causing its unity [ibid.: 61-63]. The Tartu-Moscow semiotic school made a considerable contribution to the research of poetic syntax through their description of general linguistic and poetic laws. While the first group of laws is associated with the rules of ordering units at all language levels: phonetic, lexical, morphological, and syntactic, the second group is constituted by specific restrictions, which emerge due to the existence of the poetic structure (rhyme, metre, rhythm, idea, and composition of a text) [16, p. 45-46]. The latter cause the restructuring of the language levels according to the poetic laws; on the syntactic level, they can be traced in unusual syntactic division (e.g, enjambment, word order violations, indentation, and spaces). The main factor causing additional expressive nuances and meaning shades is the ability of syntactic elements to compare and contrast in the poetic texture [ibid.: 47, 49], realized through various repetitions, parallelism, antithesis, word order changes, etc.

The emergence of the structural-synergetic approach to the study of literary texts resulted from the development of synergetics in the second half of the 20th century $[12 ; 13 ; 22]$. Currently, there are two definitions of synergetics in the scientific environment. The first one is closely connected with the etymology of the term $(\mathrm{Gr}$. synergeia - common, simultaneous action), stressing the idea of constituents interaction in the structural unity of a certain system. The other definition is linked to viewing synergetics as a theory focusing on the mechanisms of self-organization of complex open non-linear systems (physical, chemical, social, etc.) [21, p. 164]. Synergetics employs a non-linear scientific style of thinking, a specific way of world perception and understanding of the dynamics of researched objects. Unlike the classical linear scientific style, it is based on the hypothesis of alternativity and polyvariability of phenomena and processes development and the principle of non-additivity, postulating that the whole object does not equal the sum of its con- stituents [3, p. 96]. Modern synergetic studies are centered around two major schools: the Brussels school of I. Prihozhin [22] and the German school of H. Haken [12].

In the last few decades, sociology, cultural studies, history, and the organization theory have been actively using the achievements of synergetics [21]. Linguistics, in its turn, has not stayed away either. From a linguistic perspective, synergetic studies are connected with a holistic view of research objects, i.e. systemic features of the language and text phenomena with a special focus on the integration, interaction, and confluence of their parts [23, p. 291]. The first attempts of applying the theoretical base of synergetics to the contradictory nature of poetic texts can be traced to the semiotic studies of Yu. Lotman [17].

Structural-synergetic studies of poetic texts build on the assumption that the text has an integral, systemic character revealed through the method of systemic analysis. The latter follows a sequence of steps: 1) representation of the research object as a system; 2) singling out units or elements a system consists of (system setup); 3 ) description of the inner systemic relations between the units of the system (inner structure of the system); 4) description of outer systemic relations (relations of the system with the surroundings) [1, p. 65]. From this perspective, the syntactic system of a poetic text is viewed as an integral environment whose elements are coordinated and self-organized with regard to one another [9, p. 96].

Thus, in the framework of structural poetics, the basic units of poetic syntax are represented by signs (words, word-combinations, or sentences), which are viewed as interconnected and interdependent elements of the poetic system, what allows us to characterize this approach to investigating poetic syntax as structural.

Modern cognitive poetics has a powerful theoretical and methodological background, which allows scientists to conduct in-depth research of textual phenomena providing their cognitive rationale. The study of poetic syntax from the standpoint of cognitive poetics is grounded in the core principles of cognitive linguistics, cognitive semantics, and cognitive grammar in particular. The common feature of modern cognitive grammar schools is the denial of the autonomy of grammar constructions from their content. In this regard, a syntactic construction (a word-combination or a sentence) is defined as the main syntactic unit and is viewed as a two-facet entity incorporating meaning and formal means of its expression [14, pp. 497-498; 15, pp. 83-84]. The key function of the syntactic construction is structuring and symbolization of content [8, pp. 476-477].

In western cognitive studies, the meaning is mostly equated with conceptual structure [ibid.:158]. Thus, in terms of R. Langacker's Cognitive Grammar, syntactic constructions are defined as bipolar constructs comprising conceptual information and phonological form as a means of its expression [15, pp. 83-84]. Eastern cognitive schools (Russian and Ukrainian) view semantic structure as a two-facet entity consisting of the outer (semantic) level and the inner (conceptual) level expressed in the latter [5, p. 26]. The embodiment of conceptual structures in linguistic units is explicated in terms of the iconicity principle, which acts as a link between the two facets of the syntactic construction. In line with the iconicity principle, the form of any syntactic construction reflects its 
content [20, p. 399]. Thus, for example, polysyndeton, or the use of several conjunctions in close succession, reveals conceptual relations based on linking a number of elements, as presented in the example below: There is a word for it, / A simple word,/ And the word goes around./ It curves like a staircase, / And it goes like a staircase, / And it is a staircase. (Justice CAP: 154).

Along with the conceptual layer, some researchers single out the preconceptual base of syntactic constructions represented by image-schemas [11, pp. 29-30; 14, p. 497]. This assumption builds on the Spatialization of Form hypothesis formulated by G. Lakoff stating that categories in general and linguistic categories in particular are unpreconceptual and conceptual experience [ibid.: 16-23]. The latter is connected with the realization of the characteristics of human bodies and their interaction with the objects of the surrounding world [ibid.: 16-20]. Imageschema is a certain recurrent model grounded in common perceptual and sensor-motor experience acquired by people from their birth on [ibid.: 16-23; 8, pp. 45-47]. Imageschemas are linked to the so-called principle of embodied cognition whereby the term "cognition" is interpreted rather broadly and encompasses thinking, perception, bodily, sensory, and sensor-motor experience formed in individuals due to their interaction with the world around [5, p. 23]. Some of the image-schemas analyzed in cognitive grammar and cognitive semantics are UP - DOWN, FRONT - BACK, IN - OUT, FORWARD - BACKWARD, OBJECT, PART - WHOLE, BALANCE, CYCLE, etc. [14, p. 497]. Thus, for example, the poetic abstract Life, friends, is boring. We must not say so. / After all, the sky flashes, the great sea yearns, / we ourselves flash and yearn (Berryman ATL: 1715) is a complex sentence whose parts are joined asyndetically. The conderstood by people in terms of their common

struction is perceived by the reader in terms of the imageschema OBJECT organized according to the imageschema PART - WHOLE where WHOLE refers to the syntactic construction and PARTS to its elements: the sky flashes, the great sea yearns, we ourselves flash and yearn. Situated in succession, in LINEAR ORDER, they reflect the order of events of reality through the prism of the author's outlook.

Thus, this school of poetics provides a cognitive rationale for the research of poetic syntactic units. The achievements of cognitive poetics are used to clarify the principles and mechanisms of the syntactic constructions formation, to develop the methods of their analysis, and to characterize the ways of syntactic organization of contemporary poetry texts. The fact that cognitive poetologists equate semantic content of syntactic units with conceptual structure allows us to describe this approach to studying poetic syntax as conceptual.

Conclusions. A critical overview of structural and cognitive poetics with regard to the study of poetic syntax revealed that depending on the aspect emphasized by both scientific schools, syntactic poetic units have been identified with word-combinations, sentences, and texts (structural poetics) or constructions (cognitive poetics). In contrast to structural poetics, cognitive poetics approaches syntactic constructions as bipolar entities of verbal form and conceptual content, which allows the researchers to characterize them not only in terms of grammatical relations but also in terms of the linguocognitive mechanisms of their formation and functioning. Therefore, the possibility of establishing the conceptual and preconceptual structures embodied in syntactic units testifies to the innovative nature of cognitive poetic studies which are twodimensional (linguistic and cognitive) in character.

\section{REFERENCES}

1. Alefirenko N.F. (2005) Modern Problems of Language Science. Moscow: Flinta; Nauka.

2. Amirova T. A. (1999) From the History of the $20^{\text {th }}$ Century Linguistics. Structural-Functional Linguistics: Origin, Branches, Schools. Moscow: CheRo.

3. Arshinov V. Y. (2004) Synergetics of mastering the complex. In: Arshinov V. Y. and V. H. Budanov (eds) Issue 3: Cognitive Processes, 82-125. Moscow: "Kohyto-Tsentr".

4. Bart R. (1975) Foundations of semiology. In: Structuralism: "For" and "Against", 157-163. Moscow: Prohress.

5. Boldyrev N. N. (2004) Conceptual space of cognitive linguistics. Questions of Cognitive Linguistics] 1, 18-36.

6. Eco U. (1998) Absent Structure. Introduction to Semiology. St. Petersburg: TOO TK "Petropolis".

7. El'mslev L. (1960) Prolegomena to the theory of language. In: New in Linguitics. Issue 1, 264-389. Moscow: Inostrannaya literatura.

8. Evans V. and M. Green (2006) Cognitive Linguistics: An Introduction. Edinburgh: Edinburgh University Press.

9. Feshchenko V. V. (2006) Autopoetics as experience and method or about new horizons of semiotics]. In: Semitocs and Avant-garde: Anthology, 54-122. Moscow: Akademicheskiy Proekt; Kul'tura.

10. Grachova I.Ye. (2016) Quantifiers of the English Language: Diachronic aspect. Science and Education: A New Dimension, Philology IV (25), issue 105, 28-32. Available from: http://seanewdim.com/uploads/3/4/5/1/34511564/fil_iv_25_ 105.pdf (accessed 25.5.2018)

11. Johnson M. (1987) The Body in the Mind. The Bodily Basis of Meaning, Imagination, and Reason. Chicago; London.: University of Chicago Press.

12. Khaken H. (1980) Synergetics. Moscow: Izdatel'stvovo "Mir".

13. Knyazeva E. N. (2000) Topology of cognitive activity: Synergetic approach. In: Evolution. Language. Cognition, 221244. Moscow: Yazyki russkoy kul'tury.

14. Lakoff G. M. and M. Johnson (1999) Philosophy in the Flesh: The Embodied Mind and Its Challenge to Western Thought. New York: Basic Books.

15. Langacker R. W. (1987) Foundations of Cognitive Grammar: Theoretical Prerequisites. Vol. 1. Stanford: Stanford University Press.

16. Lotman Yu. M. (1996) About Poets and Poetry: Analysis of a Poetry text. Articles and Research. Notes, Reviews, Presentations. St. Petersburg: Iskusstvo.

17. Lotman Yu. M. (1998) Structure of a literary text. In: About Art, 14-285. St. Petersburg: Iskusstvo.

18. Mukarzhovskiy Ya. (1994) Structuralism in esthetics and literature studies. In: Research in Esthetics and Theory of Art, 254-274. Moscow: Iskusstvo.

19. Mukarzhovskiy Ya. (1994) About structuralism. In: Research in Esthetics and Theory of Art, 275-290. Moscow: Iskusstvo.

20. Müller W. G. (1999) The iconic use of syntax in British and American fiction. In: M. Nänny and O. Fischer (eds) Form Miming Meaning: Iconicity in Language and Literature, 393408. Amsterdam/Philadelphia: John Benjamins Publishing Company. 
21. Podlesnykh V. Y. (2006) Theory of Organization. St. Petersburg: Yzdatel'skiy dom "Biznes-pressa".

22. Prihozhin Y. (1991) Nature, science and new rationality. In: Y. Pryhozhyn, E. and E. and N. Rerikhi (eds) In Search of New Worldview, 32-41. Moscow: Znanye.

23. Semenets' O. O. (2004) Synergetics of a Poetic Word. Kirovohrad: Imeks LTD.

24. Sossyur F. de. (1999) Course of General Linguistics. Ekaterinburh: Izdatel'stvo Ural'skoho universitetata.

25. Stockwell P. (2005) On cognitive poetics and stylistics. In: Veivo H., Pettersson, B., and M. Polvinen (eds) Cognition and Literary Interpretation in Practice, 267-282. Helsinki: Helsinky University Press.

26. Strilchuk A. V. (2009) Syntactic Organization of Contemporary American Poetry Texts: Cognitive, Semiotic and Syner- getic Aspects. Ph.D. thesis. Kyiv National Linguistic University, Faculty of Lexicology and Stylistics of the English Language, Department of Germanic Philology.

27. Todorov Tsv. (2001) The concept of literature. In: Semiotics: Anthology, 376-391. Moscow: Akademicheskiy proekt; Ekaterinburh: Delovaya kniha.

28. Tsur R. (2000) Aspects of Cognitive Poetics. Available from: http://www.tau.ac.il/\%7Etsurxx/2Cognitive_Poetics.html. (accessed 25.5.2018)

29. Uspenskiy B. A. (1995) Semitocs of Art. Moscow: Shkola "Yazyki russkoy kul'tury".

30. Yakobson R. V. (2001) In search of language essence. In: Semiotics: Anthology, 111-122. Moscow: Akademicheskiy proekt, Ekaterinburh: Delovaya kniha.

\section{SOURCES}

ATL: The American Tradition in Literature (1994) New York: Mc Crawhill, Inc.

CAP: The Contemporary American Poets: American Poetry since 1940 (1980). New York: The World Publishing Company.

Структурная поэтика vs. когниивная поэтика: подходы к изучению поэтического синтаксиса

И. Е. Грачёва, А. В. Мосийчук

Аннотация. В статье рассматривается проблема изучения поэтического синтаксиса с точки зрения структурной и когнитивной поэтики. Результаты исследования выявили, что в зависимости от подхода, каждая из поэтик выделяет свои единицы, методы и принципы исследования, которые способствуют эффективному изучению поэтического синтаксиса. В статье утверждается, что на современном этапе наиболее полное изучение синтаксической организации поэтических текстов осуществляется когнитивной поэтикой, новой отраслью филологии, которая занимается изучением языковых и когнитивных механизмов формирования и функционирования литературных текстов и их элементов.

Ключевые слова: поэтический синтаксис, поэтика, поэтический текст, синтаксическая единица, конструкция. 